\title{
Wet en evangelie
}

\begin{tabular}{|c|c|}
\hline \multicolumn{2}{|c|}{$\begin{array}{l}\text { Author: } \\
\text { Gabriel M.J. van Wyk }{ }^{1}\end{array}$} \\
\hline \multicolumn{2}{|c|}{$\begin{array}{l}\text { Affiliation: } \\
{ }^{1} \text { Department Church History } \\
\text { and Church Polity, Faculty of } \\
\text { Theology and Religion, } \\
\text { University of Pretoria, } \\
\text { South Africa }\end{array}$} \\
\hline \multicolumn{2}{|c|}{$\begin{array}{l}\text { Research Project } \\
\text { Registration: } \\
\text { Project Leader: W.A. Dreyer (D) } \\
\text { Project Number: } 77370920\end{array}$} \\
\hline \multicolumn{2}{|c|}{$\begin{array}{l}\text { Description: } \\
\text { Dr Gafie van Wyk is } \\
\text { participating in the research } \\
\text { project, 'Ecumenical creeds } \\
\text { and Confessions', directed by } \\
\text { Dr Wim Dreyer, Department } \\
\text { of Church History and Church } \\
\text { Polity, Faculty of Theology, } \\
\text { University of Pretoria. }\end{array}$} \\
\hline \multicolumn{2}{|c|}{$\begin{array}{l}\text { Corresponding author: } \\
\text { Gabriel van Wyk, } \\
\text { gmjvanwyk@telkomsa.net }\end{array}$} \\
\hline \multicolumn{2}{|c|}{$\begin{array}{l}\text { Dates: } \\
\text { Received: } 05 \text { Mar. } 2018 \\
\text { Accepted: } 29 \text { Mar. } 2018 \\
\text { Published: } 08 \text { Oct. } 2018\end{array}$} \\
\hline \multicolumn{2}{|c|}{$\begin{array}{l}\text { How to cite this article: } \\
\text { Van Wyk, G.M.J., 2018, } \\
\text { 'Wet en evangelie', } \\
\text { HTS Teologiese Studies/ } \\
\text { Theological Studies 74(4), } \\
\text { a4956. https://doi.org/ } \\
\text { 10.4102/hts.v74i4.4956 }\end{array}$} \\
\hline \multicolumn{2}{|c|}{$\begin{array}{l}\text { Copyright: } \\
\text { C 2018. The Authors } \\
\text { Licensee: AOSIS. This } \\
\text { is licensed under the } \\
\text { Creative Commons } \\
\text { Attribution License. }\end{array}$} \\
\hline \multicolumn{2}{|l|}{ Read online: } \\
\hline 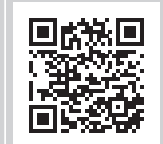 & $\begin{array}{l}\text { Scan this QR } \\
\text { code with your } \\
\text { smart phone or } \\
\text { mobile device } \\
\text { to read online. }\end{array}$ \\
\hline
\end{tabular}

\begin{abstract}
The gospel is not a new law. A clear distinction must be made between law and gospel, so that the gospel is not mistakenly understood as a new law, but as the gospel (the good news). The relationship between law and gospel must be considered carefully. Two prominent theologians, Martin Luther and Karl Barth, did just that, but in opposition to one another. This article describes and compares their respective views. Barth defends a political use of the gospel. The gospel provides believers with action instructions for the civilian life. Barth argues in terms of analogical thinking and, according to him, believers' understanding of reality is determined by their understanding of Christ. Luther, on the other hand, believes that the preaching of Christ and the life experience are in contrast. Faith and life are not identical. He understands the believer as the hearer of the gospel - as passive recipient of the grace of God. The passivity here, however, is a highly creative one. The relevance for us of the theological position defended regarding law and gospel is evident from the document 'Association of the World Communion of Reformed Churches with the Joint Declaration on the Doctrine of Justification'. The spirit of the document is clearly Barthian. Fundamental theological differences are on the table with the Lutheran position and there is no question of real consensus. Intensive study and frank ecumenical conversation is required to seek real consensus for the sake of a clear Christian testimony in the world.
\end{abstract}

\section{Vraagstelling}

Matteus 5:17 stel dat Jesus nie gekom het om die wet op te hef (verbreek, ontbind) nie, maar om dit te vervul. Dit is ook nie Paulus se mening dat Jesus, of geloof in Jesus, die wet opgehef het, of dit kragteloos gemaak het nie. In Romeine 3:31 vra hy: 'Maak ons dan die wet ongeldig deur die geloof?' Hy antwoord die vraag met presies dieselfde afwysing as wat hy in Galasiërs 2:17 gebruik: 'Dit mag nie wees nie [Beslis nie]', en voeg dan by: 'Maar ons bevestig die wet'. Uit die Nuwe Testament is dit duidelik dat ' $n$ antinomistiese benadering nie met die Christelike geloof versoenbaar is nie. Die vraag na die abrogatio legis [die afskaffing van die wet] is wel 'n wesenlike vraag volgens Paulus. Hy huldig die standpunt in dat die afsonderlike gebooie van die wet onveranderd bly geld vir die Christelike gelowiges, ondanks die feit dat die einde van die wet as heilsweg met die koms van geloof in Jesus Christus aanbreek (Ebeling 1967a:282). Dit impliseer nou nie dat ' $n$ wettiese of nomistiese benadering in die Christelike geloof gevolg behoort te word nie. Die evangelie is nie ' $n$ nuwe wet nie. Daar moet reg tussen wet en evangelie onderskei word, sodat die evangelie nie verkeerdelik as 'n nuwe wet verstaan word nie, maar dat dit wel as evangelie (goeie boodskap) verstaan word (Ebeling 2006:125-126). Dit moet deurlopend duidelik bly dat alle sondaars heil ontvang alleen deur die genade wat Christus bewerk, en nie deur wetsgehoorsaamheid nie. Wanneer die regverdiging van sondaars deur God ter sprake kom, moet dit duidelik wees dat dit op grond van die vrye genade wat God skenk, bewerk word, en nie deur enige menslike prestasie of handeling nie (Van Wyk 2017:49). Die verhouding tussen wet en evangelie moet genuanseerd deurdink word.

\section{Wet en evangelie volgens Martin Luther Agtergrond en probleemstelling}

In die vroeë gestaltes van Luther se teologie, speel die dialektiek ${ }^{1}$ van letter en gees 'n belangrike rol (Beutel 2010c:451; Danz 2013:89-90; Ebeling 2006:120). Hy gebruik dié onderskeiding om die vraagstuk te beredeneer hoe 'n oorgelewerde Skrifwoord uitgelê behoort te word sodat dit die leser in die eie tyd aangaan en in die leser se hart (naamlik die sentrum wat die persoon se hele lewe bepaal) lewend word. Die vraag op die tafel is tegelyk ook 'n vraag oor wat die eintlike saak van die evangelie is. Luther is oortuig die Skrif handel primêr oor Christus, geloof en die Heilige Gees in terme waarvan die saak van die evangelie verwoord word. Hierdie refleksiegestalte het 1.Beutel (2010c:451) wys daarop dat Luther se antitetiese denkstruktuur, in terme van die onderskeiding tussen letter en gees sowel as
die onderskeiding tussen wet en evangelie, nie dualisties is nie, maar dialekties. Dit gaan nie vir Luther oor 'n skeiding tussen twee groothede nie, maar om reg te onderskei tussen sake wat altyd saam bestaan. 
Luther se teologie nie enduit bepaal nie. Dit maak mettertyd plek vir die onderskeiding tussen wet (as dit wat oproep) en evangelie (as promissio; dit wat belowe en skenk) om die toonaangewende terminologie te word wat Luther in sy latere teologie sou aanwend (Bayer 2007:53). Dit gaan egter nie hier oor ' $\mathrm{n}$ breuk in Luther se denke nie, maar oor kontinuïteit en die rypwording van 'n uitdrukkingswyse (Ebeling 2006:120).

Luther stel in 'n preek oor Galasiërs 3:23-29 (WA 36, 8-42), wat hy op 01 Januarie 1532 gelewer het, dat die regte (eenduidige) onderskeiding tussen wet en evangelie die grootste kuns is wat die Christendom moet bemeester (WA $36,25,17-26) .{ }^{2}$ Teologie is die kuns wat uit die Woord van God aangeleer word om reg te kan onderskei; en in die kuns om te kan onderskei, is die distinctio evangelii a lege [om die evangelie van die wet te onderskei], die onderskeiding $\kappa \alpha \tau$ '

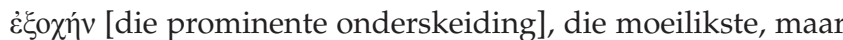
tegelyk ook die elementêrste onderskeiding (WA 40, I, 207, 17-18; WA 40, I, 526, 15; Danz 2013:88-89; Jüngel 1982a:180). Die onderskeiding tussen wet en evangelie moet van so 'n aard wees dat sowel wet as evangelie as Woord van God waardeer word, sonder dat dit met mekaar vermeng word met die gevolg dat die evangelie op 'n valse wyse tot 'n nuwe wet gemaak word, of dat die wet as evangelie verkondig word (Jüngel 1982a:181). Dié onderskeiding staan in ' $n$ baie noue verband met die Reformatoriese verstaan van die regverdiging van die sondaars (Danz 2013:89; Ebeling 2006:122). Die regte onderskeiding van wet en evangelie is nie bloot een van meer leerstukke binne 'n leersisteem nie, maar is 'n grondliggende uitgangspunt van Christelike teologie in die geheel. Met die onderskeiding tussen wet en evangelie, wil Luther beslag gee aan die Reformatoriese Skrifprinsipe sola Scriptura [die Skrif alleen]. As uitlegbeginsel geld dan vanselfsprekend tota Scriptura [die Skrif as geheel]. Aan die een kant moet gewaak word teen die sektariese houding om net ' $n$ deel van die groter geheel te verabsoluteer, maar aan die ander kant is dit ook in wese vals (en daarom moet daar ook teen gewaak word) om 'n gelyke gewig aan al die dele van die Skrif toe te ken (Ebeling 2006:123). Waar die regverdiging deur geloof as uitgangspunt geneem word, kan een tema nie bo die ander verhef word nie, maar word die regte omgang met alle moontlike inhoude van die Skrif voorberei. Die leser van die Bybel moet bereid wees om met 'n oop gemoed op 'n omvattende wyse oor die werklikheid rekenskap te gee en nie daarop uit wees om ander mense, met die Bybel as instrument in die hand, te manipuleer nie.

Aanvanklik was die onderskeiding fundamenteel in Luther se verset teen die oortuiging van die monnikedom dat mense deur goeie werke geregtigheid voor God kan verdien en die kerklike praktyke (in die besonder die aflaat) wat daaruit ontwikkel het, en waarin die evangelie tot wet verwerk is.

\footnotetext{
2.In'n tafelgesprek (Tischrede) maak Luther die outobiografiese opmerking dat in sy eie teologie (aanvanklik) niks ontbreek het nie, behalwe dat hy geen onderskeid eie teologie (anvanklik) niks ontbreek het nie, behalwe dat hy geen onderskeid tussen wet en evangelie getref het nie en dyd en me tyd en die graad van volkomenheid. Hy het egter die beslissende deurbraak (in sy teologie) gemaak toe hy die onderskeiding besef het dat die een die wet en di ander die evangelie is (WA TR 5, 210, 12-16 [nr. 5518, 1542]).
}

Die Rooms-Katolieke het van die geloof ' $n$ wettiese godsdiens gemaak en ondermyn daarom die grondliggende karakter van die geloof wat in die eerste plek mense tot Christene maak, naamlik die oortuiging dat geen wet, ook nie 'n nuwe wet (nova lex) (WA 36, 18, 21-27), tot die evangelie verklaar kan word nie. Die evangelie is in eie reg Woord van God, en deur die evangelie word mense regverdig verklaar voor God (Honecker 1990:62-63; Jüngel 1982a:181-182). Later het Luther se onderskeiding tussen wet en evangelie weer 'n belangrike rol gespeel in sy bestryding van die kettersantinomistiese ontkenning van die wet. Dié ontkenning het daarop neergekom om óf geheel en al ongebonde aan enige wet te lewe (Honecker 1990:62-63), óf om wetstekste uit die $\mathrm{Ou}$ Testament as evangelie aan te bied, soos byvoorbeeld om die opdragte aan koning Dawid om oorlog te voer, toe te pas op volgende situasies waarin die lesers hulle bevind het (Jüngel 1982a:182-183). Wat laasgenoemde betref, meen Luther, gaan dit ons - as gelowige lesers van die Bybel - nie aan nie. God se opdrag aan ons is nie om oorlog te voer nie, maar om die evangelie te glo en dit te verkondig (WA 36, 11, 23-33). Om reg tussen wet en evangelie te kan onderskei, is 'n moeilike kuns om te bemeester en wie dié kuns bemeester, is inderdaad doktor van die Heilige Skrif. Sonder die werking van die Heilige Gees, kan die onderskeiding nie verstaan word nie (WA 36, 12, 19-30; WA 36, 13, 20-25; Bayer 2007:60).

Volgens Luther is die wet God se Woord as gebod - wat ons gebied in terme van wat ons moet doen en wat goeie werke van ons eis (WA 36, 13, 28-29). Die evangelie, daarteenoor, is suiwer geskenk, gawe en heil (WA 36, 14, 22-34; WA 36, 15, 16-17). In terme van die wet tree mense as opgeroeptes, gewers en daders op, maar in terme van die evangelie is hulle ontvangers en nie doeners nie. Deur die wet is God op so 'n wyse aan die werk dat Hy mense tot dade oproep, maar deur die evangelie, daarenteen, is God op so 'n wyse aan die werk dat mense die ontvangers van sy goeie werk word (Bayer 2007:55; Beutel 2010c:451; Danz 2013:90-92; Jüngel 1982a:184). Die formele (teoretiese) onderskeiding tussen wet en evangelie is nog nie veel van 'n kuns nie. Die kuns om reg tussen wet en evangelie te kan onderskei, kom eintlik eers ter sprake binne eksistensiële situasies wanneer bepaal moet word watter Woord van God in 'n bepaalde situasie die regte woord vir die oomblik is (Beutel 2010c:451; Danz 2013:89; Ebeling 2006:126-128; Jüngel 1982a:184). Die saak word op die spits gedryf in gevalle waar die mens se gewete aangespreek word (Ebeling 2006:131-132). Die wet beskuldig mense op 'n wyse dat hulle hulself nie van die aanklag en meegaande skuld kan bevry nie (WA 7, 23, 24-24, 20; WA 36, 17, 19-25). Die harde vrae waarmee die wet ons konfronteer is: 'Waar is jy?' (Gen 3:9), en 'Waar is jou broer?' (Gen 4:9). Dawid, wat volgens 2 Samuel 12:5-7 gesê het: 'So seker as die Here leef, 'n man wat dit oor sy hart kon kry om so iets te doen, moet doodgemaak word', moet net nadat hy hierdie harde woord uitgespreek het, hoor: 'Jy is die man!' (Bayer 2007:55). Die wet spreek nie net 'n oordeel oor mense se dade uit nie, maar ook oor hulle lewens - hulle word as sondaars geïdentifiseer - en só verval hulle in vertwyfeling, in die sin dat hulle gevangenes van die aanklagte van sonde teen hulle 
word (WA 36, 19, 34-35; WA 36, 20, 20-22; WA 36, 21, 30-32). Alleen die evangelie, die woord wat mense as begenadigdes aanspreek, kan mense uit hierdie vertwyfeling red (WA 7, 23, 24-24, 20; Bayer 2007:55; Danz 2013:92-93; Ebeling 2006:133). Die evangelie is alleen as finale (letzgültige/endgültige) woord - as eskatologiese woord wat vreugde skep, bevry, moed en hoop skenk, van leuens bevry, tot waarheid bring, uit vertwyfeling red, en tot sekerheid bring - waarlik evangelie (Bayer 2007:53; Ebeling 2006:138). In die evangelie hoor verlore mense dat hulle nuwe identiteit vind buite hulself - by God wat ons as die Genadige toetree en vir ons intree (Bayer 2007:56).

Die problematiek om reg tussen wet en evangelie te kan onderskei, bestaan ook op 'n volgende vlak. Die wet self verhinder die regte onderskeiding. Dit kom daarin tot uitdrukking dat die geskiedenis van Jesus Christus as wet verkondig word. Waar die geskiedenis (historie) van Jesus verkondig word, en nie beneficia Christi, die geregtigheid en heil wat Hy vir sondaars bewerk nie, word die eer van God nie gedien nie en word evangelie tot wet verander. Só 'n moralisering van die evangelie kan volgens Luther verhoed word, deur bedag te wees op die Christologiese konsekwensies van die onderskeiding tussen wet en evangelie, wat daarop neerkom dat ook tussen Christus as gawe (donum) en voorbeeld (exemplum) onderskei moet word (Bayer 2007:57). Christus as gawe skep geloof en Christus as voorbeeld gaan ons voor in die werke van liefde (WA 10, I, 1, 11, 1-12, 2; WA 10, I, 1, 12, 17-13, 2). Net soos wat die Reformatoriese Skrifprinsipe sola Scriptura [die Skrif alleen] nie tot gevolg moet hê dat nie reg tussen wet en evangelie onderskei word nie, só moet die eksklusiwiteitspartikel solus Christus [Christus alleen] nie die gevolg inhou dat nie reg tussen Christus as gawe en Christus as voorbeeld onderskei word nie (Bayer 2007:58). Wat werklik wet en werklik evangelie is, word bepaal deur die gebruik (usus) van die Bybelse tekste en die gevolg (effectus) wat die prediking vir mense inhou. Waar mense deur die prediking voor God en in hulle gewetens aangekla word, het ons met wet te make, en waar mense deur die prediking vryspraak deur die genade van God ontvang, het ons met evangelie te make (Jüngel 1982a:185). Die evangelie maak die regte onderskeiding tussen wet en evangelie moontlik (Ebeling 2006:129-130, 148; Jüngel 1982a:186). In terme van die evangelie word die regte gebruik (usus) van die wet bepaal.

Sedert 1522 gebruik Luther die formulering duplex usus legis [twee gebruike van die wet] as 'n vaste uitdrukking (WA 10, I, 1, 454-455; Danz 2013:93) sonder om met die gebruik van die vaste uitdrukking in 'n skoolse skematisme te verval (Ebeling 1967b:64) of om die plastisiteit van sy beeldryke taalgebruik in te boet (Ebeling 1967b:59-61). Die usus verus theologicus legis (secundus usus legis) [die ware (verstandige) teologiese gebruik van die wet (tweede gebruik van die wet)] dien die cognitio pecatti [kennis van (insig in) sondes]. Die usus civilis legis (primus usus legis) [die burgerlike gebruik van die wet (eerste gebruik van die wet)] staan in diens van die instandhouding van die openbare orde, cohercere peccata [om vergrype binne perke (grense) te hou] (WA 40, I, 429, 10-11; WA 40, I, 519, 11-12; WA 40, I, 520, 4-5; WA 40, I, 530, 16-17; WA 40, I, 534, 4; Danz 2013:93-94; Ebeling 2006:154-156). Luther ken nie 'n tertius usus legis [derde gebruik van die wet] nie. ${ }^{3}$

Met sy standpunt oor die regte gebruik van die wet beveg Luther twee uiteenlopende dwalings:

1. Aan die een kant verset hy hom teen 'n standpunt soos dié van Karlstadt, wat aanvoer dat die Mosaïese wet onverkort vir Christene geld. Luther verwerp 'n wettiesbiblistiese Skrifgebruik. Soos alle ander burgers van 'n land geld die burgerlike reg ook vir Christene. Die burgerlike wette rig hulle optrede en nie meer die wette van die Ou Testament nie (WA 18, 81, 14). As sodanig het die Ou Testament vir Christene nie meer enige openbaringsgesag nie. Tog wou Luther nie soos Marcion die Ou Testament as boek uit die Christelike Bybel verwyder nie. Vir Luther lê die waarde van die $\mathrm{Ou}$ Testament nie in die sedelike en kultiese voorskrifte daarvan nie, maar in die beloftes van die Messias en die voorbeelde van geloof in God wat daarin opgeteken is. Die evangelie bevry mense om iustitia civilis [burgerlike regspleging] te skep. Mense het die vermoë om binne 'n burgerlike regsisteem sedelik verantwoordelik te lewe, maar 'n verantwoordelike lewe voor die reg maak mense nie voor God regverdig nie.

2. Aan die ander kant verset Luther hom ook teen die antinomisme. Antinomisme wys enige vorm van die gebruik van die wet van die hand. Soos reeds hierbo aangedui, verdedig Luther die blywende waarde van die wet deur twee verstandige gebruike daarvan uit te lig. Johann Agricola ( $\uparrow 1566)$ het byvoorbeeld in stryd met Luther geleer dat die wet nie God se Woord is nie en mense daarom nie kan aanspoor tot boetedoening oor hulle sonde nie. Die oortreding van die wet is nie die beweegrede vir boetedoening nie, maar wel die versaking van liefde (Honecker 1990:63-65). Agricola se teologie is ' $n$ tipiese voorbeeld van 'n teologieseensydige benadering tot die wet. Sy standpunt kan soos volg saamgevat word: geloof en kerk het alleen met die evangelie te make. As gelowiges is die Christene volkome vry van die wet en die dwingende orde daarvan. Deur geloof ontvang mense saligheid (heil). Die wet, as 'n struktuur van die wêreldlike orde, hoort in die raadsale van die wêreld en nie op die kansels van kerke nie. Die welstand van mense, wat deur die wet bevorder word, is geheel en al iets anders as hulle heil. (Honecker 1990:65)

Die regte onderskeiding van wet en evangelie as 'n stryd teen sowel nomisme as antinomisme bly steeds aktueel.

3.Gerhard Ebeling (1967b:50-53) en Werner Elert (1948:161-163) het onafhanklik van mekaar, onderskeidelik in 1950 en 1948, aangetoon dat die enigste plek in van mekaar, onderskide plek in Luther se werke (WA 39, 1, 485, 16-24) waar die tertius usus legis ter sprake gebring word ' $n$ interpolasie van Melanchthon is. Volgens Luther word die wet net aan sondaars gegee. Die geregverdigde gelowiges het geen wet meer nodig nie. Hulle lewe in Christelike vryheid en doen spontaan die goeie. Melanchthon ([1553] 2010) en Calvyn (Calvino 1559:120-121 [II, 7, 12-14]) oordeel anders deur aan te voer dat die wet ook as rigsnoer vir'n gelowige lewe dien. 
Die moraliserende nomisme van verskeie eietydse gestaltes van die charismatiese Christendom, sowel as dié van sommige vergestaltings van die ortodoks Gereformeerde Protestantisme, is oorbekend en hoef nie hier verder bespreek te word nie. Die oorweldigende meerderheid van mense in ons tyd glo dat hulle in 'n tyd lewe wat in die teken van vryheid staan. Georg Wilhelm Friedrich Hegel (1978:205) skryf: Freiheit ist die Bestimmung des Selbstbewußtseins. Die oorwinning oor die wet is in beginsel reeds afgehandel. Mense is van nature goed en vry. In hierdie sin is ons eie tyd antinomisties. Ons het nie wette nodig nie en bepaal ons eie lewens. Tog blyk dit duidelik uit Hegel se formulering dat die mense altyd eers moet word wat hulle eintlik in beginsel reeds is - aan vryheid moet altyd eers gestalte gegee word deur selfbepaling. Die mense staan daarom ook onder die dwang van die wet van selfbeskikking (Bayer 2007:59). Binne hierdie konteks is die regte onderskeiding van wet en evangelie, en die regte verkondiging van beide, ' $n$ uitdaging vir die Christelike geloofsgemeenskap.

\section{Die algemeen-menslike betekenis van die wet volgens Luther}

In teenstelling met eensydige standpunte, soos hierbo uiteengesit, onderskei Luther tussen wet en evangelie as twee gebruikswyses van God se Woord. Evangelie is die toesegging van genade, promissio [belofte] en wet, daarteenoor, is die eis van gehoorsaamheid, praeceptum [onderrig, leer] (WA 7, 50, 53; WA 36, 22, 2). Wet, in die streng teologiese sin van die woord, is vir Luther altyd gerigswoord. Dit kan niks positiefs bydra tot die heil van die mens nie en het daarom nie enige heilsbetekenis nie (Ebeling 1967b:65). Dit beskryf die fundamentele toestand van die mens as sondaar. Die aardse mense staan onder die wet, omdat hulle aan die sonde en die dood onderworpe is. Die trio lex, peccatum, mors [wet, sonde, dood] dui die fundamentele toestand, die eksistensiële grondstruktuur, van die aardse mense aan. Sterflike mense is en bly sondaars (Ebeling 1967b:65). Alle mense is sondaars ondanks hulle aansprake op medemenslikheid, naasteliefde en vertroue op God. Óf 'n mens versaak die eis van gehoorsaamheid aan die wet en is daarom skuldig voor God, óf ' $n$ mens voldoen aan die eise van die wet, maar span dan die gehoorsaamheid in as selfhandhawing en daarom selfregverdiging voor God. Die eise van die wet lei óf tot vertwyfeling (desperatio) óf tot valse eiegeregtigheid en sekerheid (praesumptio, securitas) (WA 39, I, 430, 7; WA39, I, 441, 10; WA39, I, 445, 20). Die usus theologicus legis [die teologiese gebruik van die wet] interpreteer die vervalle toestand van die mens onder die wet as die gevolg van die servum arbitrium [slaafse onderworpenheid (van mense) aan die regsbeslissing] (Ebeling 2006:152; Honecker 1990:66). ${ }^{4}$

4.Die vraag of daar' $n$ algemeen-menslike ervaring van die wet, met ander woorde' $n$ algemeen-geldende wet bestaan, kom hier op die voorgrond. In terme van Luther se teologie, skryf Gerhard Ebeling (1967b:64-65) dat die wet nie volgens Luther ' teologie, skryf Gerhard Ebeling (1967b:64-65) dat die wet nie volgens Luther ' $n$ statutêr-geopenbaarde norm is waartoe mense in ' $n$ verhouding mee staan nie, maar dat dit ' $n$ eksistensiele kategorie is waarin die teologiese interpretasie van faktiese menswees as ' $n$ eenheid byeengebring word. Wet is daarom nie ' $n$ bepaalde idee of ' $n$ versameling van wetsbepalings nie, maar die werklikheid van die vervalle mens. Die wet is primêr gebeure (Geschehen) en eers sekondêr 'n lering (Ebeling 1967a.290). Die ervaring van die realiteit van menswees klop met die ervaring van die wet. Eers wanneer sonde en dood opgehef word, is die wet ook nie meer nodig nie (WA 39, I, 355, 3 e.v.)
Die doel met die eksistensiële interpretasie van die wet is om die bestaan van die mense te verhelder en te ontsluit, sodat die evangelie as verbum externum [woord wat van buite (die mens) kom] helder en duidelik binne elke volgende konkrete situasie verkondig kan word. Die wet kan dus nie teologies korrek uitgelê word wanneer dit as wet as sodanig, los van die konkrete lewe, uitgelê word nie. Die eksistensiële interpretasie van die wet beteken om die wet aan die hand van die ervaring van mense uit te lê (Danz 2013:90; Ebeling 1967a:290-293; 2006:128, 130; Honecker 1990:67).

Om die oortuiging te ondersteun dat die wet universeel geldig is, het Luther verder ook die oortuiging gehandhaaf dat die wet (lex moralis [sedekundige of etiese wet]), en wel in die vorm van die dekaloog, in alle menslike harte en gewetens ingeprent is (WA 39, I, 361, 30; WA 39, I, 413, 14-15). Die wet word in facto [in feite] saam met die menslike bestaan aan alle mense gegee (WA 39, I, 477, 7-8). Dit beteken dat alle prediking van die wet mense net herinner aan wat hulle reeds weet (Danz 2013:91-92; Ebeling 2006:150-151). Dit kan die appèl tot humaniteit net by mense inskerp, omdat hulle kennis van die wet deur die sonde verduister is. Die prediking van die wet behoort die werklikheid van die mens as die werklikheid van sonde bloot te lê - dié werklikheid wat mense gewoonlik probeer ontken omdat hulle niks daarvan wil weet nie (Honecker 1990:67).

Luther verset hom teen geïsoleerde prediking van die wet. Blote wetsprediking werk desperatio diabolica [duiwelse wanhoop] in die hand (WA 39, I, 445, 10-11). Alleen die evangelie kan desperatio salutaris [reddende wanhoop] in die hand werk. Dit is die verkondiging van die evangelie wat van die wet as struikrower (latro) die wegwyser na Christus maak (WA 39, I, 445, 11-12; WA 39, I, 446, 3-4). Suiwer wetsprediking is volgens Luther 'n werk van die duiwel. Trouens, dit is die fynste kuns van die duiwel om van die evangelie 'n wet te maak (WA TR I, 590). Wat die wet van Moses besonders maak, is dat deur dié wet, vanuit die perspektief van die evangelie, die wese van die wet in teenstelling met die evangelie duidelik word: ó vó

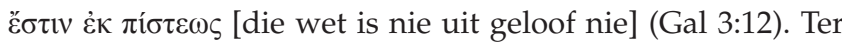
wille van die evangelie moet die wet ter sprake kom, sodat die evangelie self nie as wet misverstaan word nie. Die wet hoort in die prediking van die evangelie, want alleen as bewuste sondaars kan mense die evangelie wel as evangelie hoor (Ebeling 1967a:293; 1967b:67).

Die subjek van die usus legis [gebruik van die wet] is nie die mens nie, maar Christus of die duiwel (Ebeling 1967b:65-66). Die mens is nie die autor legis [outeur of die subjek van die wet] nie, maar wel materia legis [onderwerp van die wet] (WA 40 , I, 535, 1-2), oftewel die tema van die wet.

In die prediking moet reg tussen evangelie en wet onderskei word. Luther se wetsopvatting het die vraag na die gestaltegewing van die menslike lewenswerklikheid in die oog. Die taak van die usus civilis legis (primus usus legis) [die burgerlike gebruik van die wet (eerste gebruik van die wet)] 
is om die wêreldlike orde te beskerm deur oortredings te verhinder. Die wet het dus 'n drievoudige doel: dit wil (1) die openbare vrede bewaar, (2) aan kinders opvoeding gee, en (3) keer dat die verkondiging van die evangelie verhinder word (WA 40, I, 479 e.v.). Gelowiges moet vanselfsprekend binne die burgerlike orde in die samelewing leef en die reg respekteer as 'n beginsel om orde in die samelewing te handhaaf. Gelowiges mag nie die iustitia civilis [burgerlike geregtigheid of regverdigheid] misbruik om op iustitia spiritualis coram deo [geestelike geregtigheid voor God] aanspraak te maak nie. As gelowiges bly Christene steeds sondaars; daarom geld dieselfde wette vir gelowiges en ongelowiges. Die wet geld sonder onderskeid vir almal, vir gelowiges sowel as vir ongelowiges, maar die funksie van die wet en die betekenis van die wet verskil vir gelowiges en ongelowiges (Honecker 1990:68). Gelowiges lewe nie net onder die eise van die wet nie, want as geregverdigdes lewe hulle tegelyk ook as kinders van God in vryheid. Spontaan doen hulle dan ook dit wat goed en reg is, sonder die dwang van die wet (WA 39, I, 46, 18). Vryheid van die wet bemagtig gelowiges om self ook nuwe wette te maak om die goeie orde te dien. In beginsel leef gelowiges deur die Gees en het hulle nie enige voorskrifte nodig nie. Gelowiges moet eenduidige getuienis aan die wêreld lewer en daarom is onderlinge kommunikasie tussen gelowiges nodig - ook oor wat goed en reg is, en wat nie goed en reg is nie. Ter wille van die eenheid (gemeenskap) van die geloof moet alle gelowiges die vermanings en die gebooie van die Bybel ken en daarop ag slaan. Die eenheid van die Christelike gemeenskap moet nie in etiese oordele ondermyn word nie. Luther het bewustelik sy etiek as kommunikatiewe etiek bedryf (Honecker 1990:69).

\section{Wet en evangelie teenoor natuur en genade}

Luther se onderskeiding tussen wet en evangelie het 'n soteriologiese oriëntasie in terme van die regverdigingsgebeure. Die leidende vraag in terme waarvan Luther die onderskeid tussen wet en evangelie tref, is: wat maak mense regverdig voor God? Alle mense is aan sonde en dood onderworpe. Die begrip 'wet' word deur Luther ingespan om hierdie menslike werklikheid te beskryf. Wie aan sonde en dood onderworpe is, lewe onder die wet. Kennis van die wet, in die eintlike sin van die woord, word eers deur die aanhoor van die evangelie van verlossing deur Christus moontlik. Mense leer hulleself eers ten diepste as sondaars ken by die hoor van die evangelieverkondiging.

Luther se onderskeiding tussen wet en evangelie as fundamentele bousteen van die regverdigingsleer ${ }^{5}$ staan in skerp kontras met die Rooms-Katolieke onderskeid tussen natuur en genade (Ebeling 1967a:262, voetnota 16, 264; Ioannis Pauli PP. II 1993:17 [no. 23]). Augustinus se stelling 'Lex data, ut gratia quaereretur, gratia, data, ut lex impletur' [Die wet is dus geskenk sodat'n mens na genade soek; die genade is geskenk sodat 'n mens die wet vervul] (Augustine [412/13]

5 . Ons moet in gedagte hou dat die inhoud van die evangelie net so min die regverdigingsleer is as wat dit die wet is. Die regverdigingsleer is nie die inhoud van die evangelieboodskap nie, maar eerder die teologiese konsekwensie daarvan die evangelieboodskap nie, maar eerder die teologiese konsekwensie daarvan
(Ebeling 1967a:264). Jüngel (2011:40-42) beskryf die regverdigingsleer as 'n hermeneutiese kategorie wat die verstaan van die evangelie dien.
1914:57 [XIX, 34]) bied die grondslag vir die Rooms-Katolieke leer. Goddelike genade maak die vervulling van die wet deur mense moontlik - die genade vervolmaak die menslike natuur. ${ }^{6}$ Volgens Luther is die funksie van die evangelie nie om die menslike natuur te verander tot dié mate dat begenadigde mense die wet volkome kan vervul nie. Mense word nie deur die evangelie volkome gemaak nie; hulle ontvang nie 'n nuwe toestand (habitus) nie, maar word in 'n nuwe verhouding met God geplaas. Deur die evangelie word sondaars kinders van God (Honecker 1990:69-70).

\section{Evangelie en wet volgens Karl Barth} Barth se standpunt

Karl Barth het sy standpunt oor evangelie en wet vir die eerste keer sistematies uiteengesit in 'n voordrag met die titel Evangelium und Gesetz wat op 07 Oktober 1935 gehou is (Barth [1935] 1968:1-29). In hierdie tyd het ' $n$ hewige kerklike stryd in Duitsland gewoed tussen die sogenaamde Deutsche Christen [die Christelike ondersteuners van Adolf Hitler se politieke beleid] en die Bekennende Kirche [die belydende kerk; die Protestantse gelowiges in Duitsland wat weerstand teen Hitler se beleid gebied het]. Omdat 'n verbod op hierdie stadium reeds teen Barth deur die nasionaal-sosialistiese Duitse regering ingestel was om in die openbaar mense toe te spreek, is die voordrag deur pastor Karl Immer voorgelees. Nog dieselfde aand is Barth deur beamptes van die Gestapo na die Switserse grens vergesel om Duitsland te verlaat (Demut 2016:362; Jüngel 1982a:188, voetnota 28). Barth verset hom teen die standpunt van die Deutsche Christen dat God sy wil deur die verloop van die geskiedenis openbaar, met die gevolg dat God se wil ook uit die kerklike situasie van dié tyd afgelees kan word met die gevolg dat die burgerlike samelewing die maatstaf en die norm vir die Christelike etiek

6.s23. "Lex enim Spiritus vitae in Christo lesu liberavit te a lege peccati et mortis (Rom. 8, 2). His verbis apostolus Paulus nos immittit in considerationem cognationis inter legem (antiquam) et gratiam (novam legem) sub prospectu historiae Salutis quae in Christo impletur. Agnoscit ille munus institutorium Legis, quae homini quae in Christo impletur. Agnoscit ille munus institutorium Legis, quae homin peccatori facultatem tribuens metiendi impotentiam suam atque ab eo plenae suae
sufficientiae iactantiam auferens, eum adaperit ad invocandam accipiendamque 'vitam in Spiritu'. Tantum hac in vita nova fit plana mandatorum Dei observantia. 'vitam in Spiritu'. Tantum hac in vita nova fit plana mandatorum Dei observantia. postulat sed nemini dare potest, christifidelis quivis patefactam invenit atque datam postulat sed nemini dare potest, christifidelis quivis patefactam invenit atque datam
a Domino lesu. Sic adhuc mirum in modum sanctus Augustinus breviter astringit Pauli dialecticam de lege et gratia: 'Lex ergo data est, ut gratia quaereretur, gratia data est, ut lex impleretur' (S. AUGUSTINI De spiritu et littera, 19, 34: CSEL 60, 187). Amor et vita secundum Evangelium cogitari nequeunt ante omnia sub praecepti ratione, quia postulant quod hominis vires praetergreditur: ea effici possunt tantum quatenus sunt fructus donationis Dei, qui ad sanitatem perducit, hominis cor reficit atque transformat per gratiam suam: 'Quia lex per Moysen data est, gratia et veritas per lesum Christum facta est' (Io. 1, 17). Propter hoc vitae aeternae promissio coniungitur cum gratiae dono, atque Spiritus donum quod accepimus iam fit 'arrabon hereditatis nostrae' (Eph. 1. 14. (loannis Pauli PP. II 1993.17 (no. 23)) [23. 'arrabon hereditatis nostrae' (Eph. 1, 14. (loannis Pauli PP. II 1993:17 (no. 23)) [23. 'Want die wet van die Gees van die lewe in Christus Jesus het jou bevry van die wet van die sonde en van die dood' (Rom 8:2). Met hierdie woorde begelei die aposte Paulus ons tot die oorweging van die verhouding tussen die (ou) wet en die genade (die nuwe wet) vanuit die perspektief van die heilsgeskiedenis, wat in Christus vervul is. Hy erken die opvoedende taak van die wet, wat aan die sondige mens die kapasiteit skenk om van sy eie magteloosheid bestek op te neem en hom, deurdat hy homself van die verwaandheid van selfgenoegsaamheid ontneem, ontvanklik te maak vir die aanroeping en aanneming van die 'lewe in die Gees': alleen in die nuwe lewe is die onderhouding van die gebooie van God moontlik. Want deur geloof in Christus is ons geregverdig (vgl. Rom 3:28): die 'geregtigheid' wat die wet vereis, maar dit aan niemand kan skenk nie, vind elke opregte geopenbaar en geskenk deur die Here Jesus. So bied die heilige Augustinus opnuut op 'n wonderlike manier 'n kort samevatting van Paulus se dialektiek van wet en genade: 'Die wet is dus geskenk, sodat 'n mens na genade soek; die genade is geskenk, sodat 'n mens die wet vervul'. Die liefde en die tweede lewe, volgens die evangelie beskou, kan nie voor alles wees ond lief onder opdrag van die rede nie, want dit wat die wet verlang, gaan die kragte van die mens te bowe: daardie resultate is alleen moontlik as vrug van 'n gawe van God, wat tot heil bring, die hart van die mens herskep en deur sy genade hervorm: 'Immers, die wet is deur Moses geskenk, die genade en die waarheid is deur Jesus Christus geskenk' (Joh 1:17). Omdat die belofte van die ewige lewe verband hou met die aanbod van die genade en die geskenk van die Gees, wat ons alreeds ontvang het, is dit 'die waarborg van ons erfenis' (Ef 1:14)]. 
word (Honecker 1990:71; Maurer 2016:130). Hy was oortuig dat die historiese werklikheid God nie openbaar nie. Geskiedenis is altyd meerduidig en kan nie vertolk word as die orakel van God se wil nie. Hy was verder van oortuiging dat die antitetiese teenstelling van wet en evangelie in die Duitse evangeliese teologie die vernaamste oorsaak was dat die kerk in Duitsland nie wesentlike weerstand gebied het teen die nasionaal-sosialistiese teologie nie (Demut 2016:362). Die feit dat Barth (1959:427) 24 jaar later sy standpunt van 1935 oor die verhouding tussen evangelie en wet nog nie gewysig het nie, maar dit tot 'eisernen Bestand' [vaste voorraad, dus, vername bousteen] van sy Kirchliche Dogmatik verklaar het, dui op die belang van die saak vir sy teologie. Dit sou ' $n$ fout wees om te meen dat Barth se standpunt oor die verhouding tussen wet en evangelie niks meer behels as politieke polemiek nie. ${ }^{7}$

Luther en Barth volg uiteenlopende benaderings ${ }^{8}$ in hulle nadenke oor die Woord van God. Waar dit vir Luther met die onderskeiding tussen wet en evangelie oor die onderskeiding van twee gebruikswyses van die Woord van God gaan wat op 'n dialektiese wyse eenheid in God self vind (Jüngel 1982a:187), gaan dit vir Barth oor drie onderskeibare gestaltes van God se Woord, naamlik openbaring (geopenbaarde Woord van God), Bybel (geskrewe Woord van God) en verkondiging (verkondigde Woord van God). Hoewel Barth die openbaring as die eerste gestalte van God se Woord beskryf, wat beide ander gestaltes van die Woord begrond, is geeneen van die gestaltes van die Woord meer of minder as die ander nie. Ons ken die openbaring van God egter net indirek deur die Skrif en die verkondiging. Volgens Barth is daar net een analogie vir die leer oor die Woord van God en dit is die leer oor die Drie-enigheid van God (Barth 1947:124-125). Barth self meen die leer oor die drie gestaltes van God se Woord is nie nuut nie, maar algemeen (tradisioneel) Christelik. Hy gebruik Luther as voorbeeld om hierdie standpunt te illustreer (Barth 1947:125-128). Jüngel (1982a:187) is in die kol wanneer hy oordeel dat Barth en Luther oor verskillende sake handel met hulle nadenke oor die Woord van God en dat hulle teologie op hierdie punt in beginsel nie met mekaar vergelyk kan word en teenoor mekaar afgespeel kan word nie.

Karl Barth se oorspronklike uitgangspunt was nie om die werking en die funksie van die wet, die usus legis, te beskryf nie, maar om die vraag te beantwoord hoe mense tot kennis van die wet kom. Sy antwoord op die vraag is dat mense tot kennis van God se wet kom deur die evangelie, wat die openbaring van God is. Sy vertrekpunt is dus nie die regte

7.Uit die voorwoord van die eerste band van die Kirchliche Dogmatik, wat in 1932 geskryf is, kom dit duidelik aan die lig dat Barth met sy teologie nie enige politieke, maatskaplike of ekonomiese belange wou dien nie, maar wel die verkondiging van die waarheid van God se Woord (Barth 1947:XI, Greschat 2016:155).

8.Die feit dat Luther en Barth uiteenlopende teologiese benaderings gevolg het, beteken nie dat daar geen raakpunte tussen hulle onderskeie benaderings bestaan het nie. In'n sekere sin ontwerp Barth verskeie aspekte van sy teologie in dialoog het nie. In ' n sekere sin ontwerp Barth verskeie aspekte van sy teologie in dialoog met Luther. Plasger (2016:37) Bordeel dat Barth hself deurlopend krities georienteer het aan die teologie van Luther en Calvyn. Maurer (2016:127) beskryf Barth se verhouding met die Lutherse teologie as unubersichtlich und ambivalent, waaruit hy aflei dat Barth se verstaan van Luther se teologie getuig van 'n kompleks verhouding van aanknoping en kritiese afstand. onderskeiding tussen wet en evangelie nie, maar die regte toevoeging van die wet tot die evangelie (Jüngel 1982a:187). Alleen binne die raamwerk van die evangelie kan die wet reg verkondig word (Demut 2016:361).

Om Barth se standpunt oor die verhouding tussen evangelie en wet te probeer verduidelik, is dit dalk raadsaam om as uitgangspunt te neem dat hy daarop wys dat die feit dat God met mense praat ' $n$ vrye onverskuldigde weldaad van Hom is. Dat God met ons praat, is onder alle omstandighede reeds die uitdrukking van sy genade (Barth [1935] 1968:2). ${ }^{9}$ Barth se verstaan van die verhouding tussen evangelie en wet word deur sy opvatting van die Woord van God as genadedaad van God bepaal. Hy ontken nie die tweeheid van evangelie en wet nie. Hy ontken ook nie dat evangelie en wet soms in teenstelling met mekaar bestaan nie, maar hy benadruk dat die eenheid van God se Woord groter gewig dra as die tweeheid van evangelie en wet (Barth [1935] 1968:2). Die tweeheid van evangelie en wet mag nooit daartoe lei dat abstrak tussen die genade van God en die toorn van God, tussen God en God skeiding gemaak word nie (Jüngel 1982a:189). ${ }^{10}$ In die wet het ons nie met 'n ander God te make as met die God van die evangelie nie. Barth meen Luther se onderskeiding tussen wet en evangelie hou inherent die gevaar in om dualisties tussen die verborge en openbarende God te onderskei (Barth 1948a:70).

Die feit dat Barth (1959:427) die saak van die verhouding tussen evangelie en wet tot 'eisernen Bestand' van sy Kirchliche Dogmatik verklaar het, beteken nie dat dit as 'n tema in dié werk sistematies aan die orde gestel word nie. Die intensie van Barth met betrekking tot die saak kulmineer in die Kirchliche Dogmatik, waar mense se konfrontasie met hulle sonde aan die orde gestel word. Hier kom dit duidelik aan die lig dat sy ommekeer van die bewoording wet en evangelie na evangelie en wet veel meer as net 'n formaliteit behels. Anders as in die tradisionele benadering wat in dogmatiek gevolg word, behandel hy nie eers die sondeleer om dan in die lig daarvan, en as antwoord daarop, die verlossingsleer aan die orde te stel nie; maar nadat hy die Christologie behandel het, bring hy die sonde (eintlik die sondaarmens) binne die versoeningsleer ter sprake (Barth 1953:396), en wel binne drie kontekste, naamlik: Des Menschen Hochmut und Fall, Der Mensch der Sünde im Spiegel des Gehorsams des Sohnes Gottes (Barth 1953:395-458), Des Menschen Trägheit und Elend, Der Mensch der Sünde im Licht der Herrschaft des Menschensohnes (Barth 1955:423-452) en Des Menschen Lüge und Verdammnis, Der wahrhaftige Zeuge (Barth 1959:425-499).

9.'Daß Gott mit uns redet, das ist unter allen Unständen schon an sich Gnade' (Barth [1935] 1968:2).

10.Barth (1948b) skryf oor Luther se teologie:Luthers Stellung zu dieser Sache läßt sich auf keinen eindeutigen Nenner bringen. Er hat als Ausleger des Alten und des Neuen Testamentes oft reichlich abstrakt und schematisch, in einem Paulinismus, der nicht der des Paulus selbst war, zwischen Gesetz und Evangelium, zwischen der nicht der des Paulus selbst war, zwischen Gesetz und Evangelium, zwischen Geboten und Verheißungsworten und dann wohl auch zwischen Alten und Neuen Testament im ganzen unterschieden, um sie dann doch auch wieder ... in
überraschender Klarheit in ihrer ursprünglichen und endlichen Einheit zu sehen und überraschender Klarheit in ihrer ursprünglichen und endlichen Einh zu verstehen. Wir halten uns an diesen zweiten Luther ( $p$. 340). 'n Luther wat sy eie saak dien en waarby hy hom skaar, en 'n Luther waarvan hy hom distansieer, nie reg laat geskied aan die integriteit van Luther se teologie nie hom distansieer, nie reg laat 
Mense kan nie selfstandig tot die insig kom dat hulle boos is nie (Barth 1953:397). Juis vanweë die feit dat hulle sondaars is, kan hulle nie selfstandig hulle sonde ontdek nie (Barth 1953:398). Om hierdie rede wil Barth nie enige menslike ervaring met betrekking tot die problematiek van mense se eie lewens met die teologiese begrip sonde in verband bring nie (Barth 1953:398). 'n Mens kan alleen insig in sonde as sonde kry coram deo [voor God] en per lumen revelationis dei [deur die lig van die openbaring van God] (Barth 1953:400). Hy meen die konfrontasie van mense met ' $n$ abstrakte wet en 'n abstrakte God is ' $n$ willekeurige produk van die menslike verstand wat die ware God onteer en die ware wet ontledig (Barth 1953:401-403). Die Bybelse uitsprake oor mense as sondaars staan in verband met die Ou Testamentiese genadeverbond van God met sy volk, of met die verskyning, werk en persoon van Jesus Christus, ter vervulling van God se verbond met die mense (Barth 1953:406; Maurer 2016:128). Die wet oortuig mense nie buite die evangelie van hulle sonde nie. Die wet word alleen in die evangelie outentiek vertolk om mense tot kennis van hulle sonde te bring (Barth 1953:437). Waar God se Woord vlees word en vlees is, word oopgevlek dat die mens vlees is, en wat dit behels dat die mens vlees is. Waar God se genade ervaar word, daar word dit bekend dat mense sonde doen en sondaars is (Jüngel 1982a:195). Jesus Christus is die kenbron van God se vrye en soewereine genade (Barth [1935] 1968:7). Die openbaring van Jesus Christus, die verkiesing, die genade en God se troue verbond met die mensdom omvat, konstitueer, impliseer en integreer volgens Barth elke aanspraak van God op mense (Demut 2016:363). Barth se benadering word bepaal deur die oortuiging dat God se verbond wet en evangelie omvat.

Anders as Luther is Barth se benadering nie soteriologies nie, maar openbaringsteologies en gnoseologies (Honecker 1990:70). Hy bring evangelie en wet op 'n intensiewe wyse in verband met mekaar, deur 'n logies problematiese formulering ${ }^{11}$ te gebruik: das Gesetz [... ist ...] die notwendige Form des Evangelium, dessen Inhalt die Gnade ist (Barth [1935] 1968:9). Wat hy met die formulering probeer aanvoer, kan moontlik soos volg saamgevat word: wat alles as wet van God geld, kan alleen in die lig van die evangelie bepaal word. Daar bestaan nie enige evangelie wat mense nie ook as wet aanspreek nie. Die evangelie is die Woord van God wat sy genade aan mense toespreek. Die wet is die Woord van God wat aanspraak maak op mense met die oog op die genade van God. Deur die wet kom die evangelie aan die woord, wat inhoudelik as indikatief van die genade die vorm van die genadige imperatief aanneem (Jüngel 1982a:195).

Barth ([1935] 1968:1, 18, 27-29) gee in Evangelium und Gesetz wel ook toe dat die volgorde wet - evangelie 'n bepaalde reg het, in die sin dat dit die volgorde sonde - geregtigheid beskryf. Die wet word vir sondaars in die hand gegee

11.Ebeling (1967a:277-279) en Bultmann (1976:90) het reeds oortuigend aangedui dat verskeie aspekte van Barth se formulering onduidelik is - sowel in sy keuse van (a) begrippe as in die logiese konsekwensies van die formulering. Later wys Ebeling (1985:549-551) daarop dat Barth in sy beskrywing van die verhouding tussen we en evangelie deur die gebruikmaking van die kategorieë inhoud en vorm, wat van 'n suiwer logiese aard is, alleen maar net sy vooropgestelde eenheidsgedagte dien, en dat hy met die benadering niks meer bereik as om die veronderstelling waarvan hy uitgaan te handhaaf nie.
(Barth [1935] 1968:9). Sondaars maak van die goeie wet van God die wet van sonde en van die dood (Rom 8:2). Die sonde bedrieg ons deur die wet, en daarom bedrieg dit ons ook oor die wet (Barth [1935] 1968:18). Word die wet egter as deel van die evangelie verstaan, kan die werklikheid van die sonde wel die eenheid van wet en evangelie problematiseer, maar dit kan nie die eenheid versteur nie, want binne die raamwerk van die evangelie word die wet die blye boodskap aan werklike sondaars (Barth [1935] 1968:24). Die boodskap van die evangelie is egter dat mense onder God se genade lewe en nie onder die sonde en die toorn van God nie. In die aangesig van die sonde sorg God daarvoor dat die evangelie, die goeie boodskap, aan mense die bevryding deur en vir die vrye God verkondig. Die karakter en die gestalte van die ware wet, die wet van God, is ook toesegging van God se genade, op dieselfde wyse as wat die tafels van die tien gebooie in die ark van die $\mathrm{Ou}$ Testamentiese verbond bewaar was (Barth 1959:427). As uitvloeisel van die argument wat Barth (1948a) in hierdie verband voer, kan hy skryf:

Etiek as leer van God se gebod verklaar die wet as die gestalte van die evangelie, dit wil sê, as die norm wat mense deur die verkiesende God as heiliging ervaar. ${ }^{12}$ (bl. 564)

God se aanbod van genade aan mense gaan altyd sy aanspraak op hulle gehoorsaamheid teenoor Hom vooruit. Binne die verbond gaan die evangelie die wet altyd vooraf (Barth 1948a:567). Die Woord van God is 'n begrip wat sowel evangelie as wet omvat (Barth ([1935] 1968:4). Die evangeliese vermaning aan mense om gehoorsaam aan God te lewe, volg op die verkondiging van die goddelike genade (Barth ([1935] 1968:10). Weereens: die wet is niks anders as die noodwendige vorm van die evangelie nie en die inhoud van die evangelie is genade (Barth ([1935] 1968:11; Demut 2016:364). Etiek as die lering van God se gebod verklaar die wet as die gestalte van die evangelie, as die heilsame binding en verpligting van die mense aan die grondliggende aanbod van God se genade (Barth 1948a:564). Geloof gaan gehoorsame handeling vooraf, en net so gaan die indikatiewe waarheid van die evangelie die imperatiewe vermaning tot gehoorsaamheid vooraf (Barth ([1935] 1968:13). Die evangelie as die krag van die wet (Barth 1948a:628) maak enige wettiese interpretasie van die wet onmoontlik (Barth 1948a:669). Evangelie en wet maak mense vry (Barth 1948a:650) - 'n gelowige handel in vryheid in terme van die volmag ( $\pi \alpha \rho \rho \eta \sigma i ́ \alpha)$ van die wet en nie gedwonge nie. Barth verstaan die wet as die gebod - as die gebod om die evangelie ter harte te neem (Demut 2016:364; Honecker 1990:72).

Barth se standpunt stem baie ooreen met dié van Melanchthon en Calvyn wat die sogenaamde derde gebruik van die wet (tertius usus legis) die eintlike onderwerp van die teologiese leer oor die wet maak. Hy meen dat 'n mens alleen deur die Christusopenbaring tot kennis van die wet kom en ontken enige ander openbaringsaanspraak naas of onafhanklik van die Christusopenbaring. Volgens hom is evangelie en wet

12.'Ethik als Lehre von Gottes Gebot erklärt das Gesetz als die Gestalt des Evangeliums, d.h. als die Norm der dem Menschen durch den ihn erwählenden Gott widerfahrenden Heiligung' (Barth 1948a:564). 
onlosmaaklik een en die evangelie geniet altyd prioriteit bo die wet (Demut 2016:363; Ebeling 1985:562).

\section{Reaksie op Barth se standpunt}

Barth se standpunt het uit verskeie oorde, maar veral uit Lutherse geledere, hewige kritiek ontlok. Hier word net enkele belangrike kwessies aan die orde gestel. Edmund Schlink (1956:323-335; 1983:211-251, 416-478) wys daarop dat Barth die begrip wet nie as die vó Moses, gebruik nie, maar wel as die Pauliniese parainesis. Paulus gebruik deurgaans die volgorde evangelie - paraklēsis, of indiktatief - imperatief, in sy briewe. Paraklēsis is egter vir Paulus nie identies met wet (nomos) nie. Paraklēsis versoek nie dat die mense in terme van wetsonderhouding moet presteer nie, maar maak die charismatiese bestaan van die gelowiges in vryheid moontlik. Evangelie en paraklessis is nie soos evangelie en wet wedersyds uitsluitend nie. By Paulus is die onderskeiding tussen wet en evangelie ' $n$ onderskeiding in terme van die heilsgeskiedenis: ' $n$ mens kan nie as gelowige tegelyk onder die wet en die genade lewe nie (Van Wyk 2017:113-117). Christus bevry mense om nie langer onder die wet te lewe nie, maar onder die genade. Volgens Schlink maak Barth nie erns met die grondstruktuur van Paulus se denke in terme van die onderskeiding tussen wet en evangelie nie. Hy behandel net die tertius usus legis [derde gebruik van die wet], die vermanende funksie van die gebod vir die gelowiges. Die grondliggende Lutherse onderskeiding tussen die primêre en sekondêre gebruike van die wet moet in Barth se teologie plek maak vir die Christelike openbaringsleer (Honecker 1990:75). Barth (1959:425-426) se antwoord op Schlink dat Christus die een Woord van God is, bly onbevredigend omdat, hoewel dit abstrak en tydloos waar is dat eers die evangelie sonde voor God reg kwalifiseer, dit wel ook so is dat sonde as 'n werklikheid die verkondiging van die evangelie voorafgaan. Bayer (2007:55) verduidelik die saak soos volg: in alle mense se lewens is die wet altyd voor die evangelie werkend teenwoordig, en in hierdie sin gaan dit die evangelie vooraf. Dit beteken egter nie dat die wet 'n prinsipiële voorrang bo die evangelie het nie. Saaklik geniet die evangelie altyd voorrang bo die wet.

Jüngel (1982a:202) wys daarop dat die onversoenbare standpunte van Luther en Barth oor die verhouding tussen wet en evangelie ten diepste met Barth se antropologiese uitgangspunt te make het. Barth is oortuig dat mense as persone bestaan, omdat (en net omdat) hulle handel. ${ }^{13} \mathrm{Hy}$ is oortuig dat mense alleen mense is omdat hulle hulself kan bepaal (Barth 1948b:400; Maurer 2016:128). Mense lewe deur dade van eie en vrye keuse (Barth 1948b:400). Volgens Barth is mense per definisie slegs verstaanbaar as handelende wesens wat hulle eie lewens bepaal. Die evangelie spreek mense as handelende wesens aan en daarom spreek die evangelie mense in die vorm van die wet aan. Luther, daarenteen, meen dat mense die evangelie net passief kan ontvang. Die passiwiteit van die gelowige hoorders van die evangelie is wel hoogs kreatief, maar dit is die Woord van God wat mense buite hulleself roep om die heil te ontvang wat God aanbied. Hierdie nos extra nos esse [ons wat buite onsself is] (WA 40, I, 589, 8) is die grondstruktuur van die hoorders van die Woord - ja, dit is die grondstruktuur van die menslike bestaan as sodanig (Jüngel 1982a:205). Ebeling (1985:563) toon die problematiek van Barth se posisie aan deur daarop te wys dat 'n gelowige antwoord op die evangelieverkondiging nie die aanvaarding van ' $n$ nuwe aksieprogram behels nie, maar wel om God se oordeel oor jou sonde te aanvaar, skuld voor Hom te bely en, wanneer genade aan jou toegespreek word, jou geloof te bely. Hierdie handelinge is nie blote inisiasieritus tot 'n Christelike lewe nie, maar dit deurdrenk, vorm en gee gestalte aan 'n lewe in geloof.

\section{Die tertius usus legis [derde gebruik van die wet] as teologiese probleem}

Die opvatting van die tertius usus legis [derde gebruik van die wet] het in gebruik gekom in die teologie van Melanchthon. Die opvatting het met verloop van tyd ontwikkel en stelselmatig beslag gekry in sy denke. ${ }^{14}$ In die eerste uitgawe van Melanchthon ([1521] 1997) se Loci word die tema nog nie aan die orde gestel nie. Die saak of tema van die tertius usus legis word reeds aan die orde gestel in die tweede uitgawe van sy Loci van 1535 (Ebeling 1967b:57), sonder dat dit al terminologies beslag gekry het. Die tema word nuut verwerk vir die derde uitgawe van dié werk wat vanaf 1556 verskyn het, en daar word spesifiek na die leer van die triplex usus legis verwys teenoor die duplex usus legis wat vroeër deur Melanchthon aan die orde gestel is (Ebeling 1967b:57). Die opvatting van die tertius usus legis het van toe af in die teologiegeskiedenis navolging gevind.

Melanchthon redeneer dat die gelowiges wel vry is van die verdoemenis van die wet, maar dat die wet as ordinatio divina [goddelike reëling] steeds vir hulle geld. In 'n verwerkte vorm het sy leer oor die tertius usus legis offisieel neerslag gevind in die Evangelies-Lutherse Kerk.

Artikel VI van die Konkordienformel van 1577 handel oor die derde gebruik van die wet, en Artikel V, wat dit voorafgaan, handel oor die verhouding van wet en evangelie. Die Konkordienformel is in die bundel Die Bekenntnisschriften der evangelisch-lutherischen Kirche (Dingel [1577] 2014:1184-1610) opgeneem. Hierdie bundel bevat al die belydenisskrifte van die Evangelies-Lutherse Kerk. Die dokument stel dat die begrip evangelie in die Christelike verkondiging met 'n dubbele betekenis gebruik word. Dit word in die algemene sin van die woord gebruik om op die omvattende Christelike verkondiging te dui, wat vermaning in terme van die wet insluit. Die begrip het ook 'n meer toegespitste gebruik, naamlik om die genadeverkondiging as sodanig aan te dui. Die Konkordienformel, Artikel V, formuleer ortodoks in terme van die kerklike leer om verwarring rondom die meerduidige betekenis van die begrip evangelie op te klaar. Twee leerwyses word van mekaar onderskei, naamlik openbaring as oorkoepelende leer van die goddelike wil,

14. Die ontwikkelingsgeskiedenis van sowel die saak as die terminologie kan nagelees word by Ebeling (1967b:53-58). 
wat evangelie en wet insluit, en evangelie, wat die Christelike leer (doctrina) as die plaasbekledende versoening van Christus verwoord. Die Konkordienformel onderskei nie soos Luther 'n lewe onder die wet of onder die evangelie nie, maar onderskei tussen wet en evangelie as twee gestaltes van die Christelike leer. Waar dit vir Luther oor gebeure gegaan het in sy onderskeiding tussen wet en evangelie, gaan dit vir die Konkordienformel oor twee gestaltes van die kerklike leer (Honecker 1990:75). Die wet maak God se wil en bevele aan die mense bekend, maar dit skenk nie self aan mense die krag en die vermoë om dit te vervul nie. Die Gees skenk egter deur die evangelie aan mense die krag om die wet te vervul.

Gerhard Ebeling (1967a:266-271) dui die inherente problematiek aan van die benadering wat deur die Konkordienformel gevolg word. Wet en evangelie dui nie in die Nuwe Testament op twee leerinhoude wat teenoor mekaar afgespeel kan word nie. Hy wys daarop dat, in terme van Paulus se teologie, wet en evangelie onder die begrip $\delta 1 \alpha \theta \eta \dot{\kappa \eta}$ [verbond, testament, wil] tuisgebring kan word. 'n Ou en 'n nuwe verbond kom ter sprake. Die twee verbonde word nie deur Paulus in terme van inhoud teenoor mekaar gestel nie, maar in terme van wat hulle bewerk. Waar die wet nie lewe en Gees kan gee nie, maar die dood bring, is die nuwe verbond die gebeure waar die lewendmakende Gees geskenk word. Dit gaan om die werking van verkondigingsgebeure. Die nuwe dui nie op 'n nuwe (volgende) historiese tydvak wat aanbreek nie, maar op die eskatologiese (beslissende) lewensgewende werklikheid wat aangekondig word (Beutel 2010c:452).

In die Institutio christianae religionis (Calvino 1559:120-121 [II, 7, 12-14]) verdedig Calvyn die mening dat mense deur die wet leer om die wil van God te ken, om gehoorsaam aan sy wil te lewe, en wat geregtigheid behels. Die praecipuus usus legis [vernaamste gebruik van die wet] is die tertius usus legis (Calvino 1559:120 [II, 7, 12]). Die wet lig gelowiges in oor die wil van God. As ordeningsmag het die wet gesag oor die gelowiges. God handel wetgewend (legislatief) deur die wet. Wet en evangelie is nie in teenspraak nie, maar die evangelie manifesteer duideliker as die wet (Calvino 1559:148 [II, 10, 4]).

\section{Gevolgtrekking}

Barth ([1935] 1968:9), soos Calvyn (1559:120 [II, 7, 13]), se standpunt dat die wet die vorm van die evangelie is, vind 'n vertrekpunt in die Ou Testament, veral in Psalm 19 en 119. In Deuteronomium is die paranese, die imperatief, 'n uitvloeisel van die verbond wat God met Israel gesluit het en wat as die indikatief van genade geld. Agter die vraag na die verhouding tussen Barth se wetsopvatting en die verbondsbegrip van die Ou Testament, skuil die meer fundamentele vraag na die geldigheid van die Ou Testament vir Christelike gelowiges en die meegaande vraag na die kontinuïteit of diskontinuïteit tussen die onderskeie geloofstradisies en die heilsgeskiedenis onderliggend daaraan.

Paulus, by wie Luther aansluiting vind, het die wet (vó eenduidig as heilsweg afgewys. Die direkte teenstelling

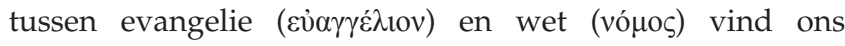
egter nêrens in Paulus se briewe nie. Hy beskryf wel 'n teenspraak tussen $\dot{\varepsilon} \pi \alpha \gamma \gamma \varepsilon \lambda i ́ \alpha$ [belofte] en vó $\mu$ os [wet] in sy briewe (Rom 4:13; Gal 3:18, 21). Volgens Luther is die wet (lex) as die vernaamste uitgangspunt vir menswees en lewe, 'n eksistensiële kategorie. Paulus het die wet binne die heilsgeskiedenis georden: Abraham het nog sonder die wet gelewe (Rom 4; Gal 3:6-16, 4:21-31). Dit was eers Moses wat die wet gebring het (Gal 3:17). Die wet, wat die sonde oopvlek en aan die lig bring, is 'n tussenspel in die

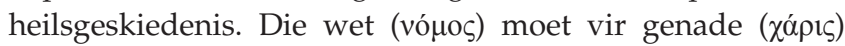
plek maak (Rom 2:25, 6:14, 7:4). Hierdie opeenvolging van wet en evangelie in terme van tyd word deur Luther verwerk tot 'n voortdurende dialektiese spanning tussen wet en evangelie in die lewens van mense. Luther beroep hom in die onderskeiding tussen wet en evangelie op Paulus, maar lê dan die wet en die evangelie binne 'n nuwe situasie nuut uit. Paulus se heilshistoriese wetsopvatting word verwerk tot 'n eksistensieel-antropologiese wetsopvatting (Honecker 1990:79). Volgens Paulus en Luther dien die teologiese gebruik van die wet nie in die eerste plek die ontwerp van etiese aanwysings of geopenbaarde leerstukke nie, maar dien dit as 'n heilsweg. Dit gaan vir hulle oor die soteriologiese relevansie van die wet.

Gerhard Ebeling (1985:428-573) meen Barth ken 'n usus politicus evangelii [politieke gebruik van die evangelie]. Die evangelie bied aan gelowiges handelingsaanwysings vir die burgerlike lewe. Barth redeneer in terme van analogiese denke, en die verstaan van Christus bepaal die gelowiges se verstaan van die werklikheid. Luther, daarenteen, meen dat die verkondiging van Christus en die lewenservaring in kontras met mekaar staan. Geloof en lewe is nie identies nie. Eberhard Jüngel (1982a:200) het aangetoon dat Barth die begrippe wet en evangelie supralapsaries verstaan. Die Christologiese oergeskiedenis behels God se genadige verkiesing van die mense reeds voor alle tye. Hierdie ewige oergeskiedenis bestaan (postlapsaries) voort na die sondeval. Daar bestaan inderdaad 'n grondige en onversoenbare teenspraak tussen die denke van Luther en Barth. Volgens Barth is mense handelende persone wat hulle eie lewens bepaal. Mense se omgang met die wet as handelingsnorm dui op hulle gehoorsaamheid of ongehoorsaamheid aan God. Om aan die wêreld gestalte te gee, is 'n Christelike plig. Toegepaste geloof is politieke godsdiens. Uit die evangelie kan direkte aanwysings vir handeling in die openbare politieke lewe afgelei word. Luther, daarenteen, verstaan die gelowige as hoorder van die evangelie - as passiewe ontvanger van die genade van God. Die passiwiteit wat hier ter sprake kom, is egter 'n hoogs kreatiewe passiwiteit (Ebeling 2006:134-136; Jüngel 1982a:205; Maurer 2016:131). Die evangelie plaas mense as hoorders van die evangelie 'buite hulleself' (posit nos extra nos, WA 40, I, 589,9). Daar moet fundamenteel onderskei word tussen wet en evangelie, tussen die situasie voor God en dié voor die mense (coram deo en coram hominibus), tussen geloof en werke (Honecker 1990:80). Barth en Luther probeer met hulle teologie antwoorde vind oor die aard van die verhouding tussen 
geloof en werke, net soos wat Paulus en Jakobus dit ook vroeër gedoen het. Ook ons sal vir onsself antwoorde oor die saak moet vind wat relevant is vir ons tyd en die vraagstukke wat ons lewens bepaal.

Volgens Luther put teologie uit twee bronne, naamlik die Heilige Skrif en die menslike ervaring (Beutel 2010a:454-459; 2010b:444-449). Etiese norme kan daarom nie as tydlose waarhede verkondig word wat vir tyd en ewigheid geproklameer word nie. Binne elke volgende situasie moet opnuut, in die lig van God se Woord, rekenskap gegee word oor wat reg is en wat nie reg is nie. Christelike etiek opereer nie met 'n unieke stel reëls wat verskil van die uitgangspunte van ander etiese benaderings nie. Rasionele argumente gee die deurslag oor wat die regte benadering in elke volgende situasie is. Die wet is daarom nie 'n morele kode wat rasionele etiese denke ophef nie. Wanneer daar in terme van die Christelike etiek beslissings gevel word oor wat die regte optrede binne 'n gegewe situasie is, behoort die beslissings nie net oortuigingskrag vir gelowiges te hê nie, maar ook vir alle ander mense. Etiese argumente wat in terme van Christelike oortuigings aangevoer word, sal soos alle ander etiese argumente, ook die toets van redelikheid en algemeengeldigheid moet kan deurstaan.

\section{Aktualiteit vir ons situasie}

Die blywende relevansie en belang van die teologiese posisie wat ingeneem en verdedig word rakende die verband tussen wet en evangelie, blyk duidelik uit die dokument Association of the World Communion of Reformed Churches with the Joint Declaration on the Doctrine of Justification ${ }^{15}$ (World Communion of Reformed Churches 2017), wat in 2017 deur die World Communion of Reformed Churches by die sewejaarlikse Algemene Vergadering van dié liggaam aanvaar is, wat vanaf 29 Junie tot 07 Julie 2017 in Leipzig, Duitsland, plaasgevind het. Die Nederduitsch Hervormde Kerk van Afrika (NHKA) is in 2014 toegelaat as lid van die organisasie van Gereformeerde Kerke, en het amptelik op die vergadering sitting geneem. By implikasie assosieer die NHKA met die handelinge van die World Communion of Reformed Churches. Sedert dié vergadering het die kerkleiding van die NHKA, nie enige kritiese voorbehoude publiek gemaak rakende die dokument nie.

\footnotetext{
15. Die Joint Declaration on the Doctrine of Justification (The Lutheran World Federation \& The Catholic Church 1999) is op 31 Oktober 1999 deur verteenwoordigers van die Rooms-Katolieke Kerk (spesifiek The Pontifical Counc for Promoting Christian Unity) en The Lutheran World Federation onderteken. Hoewel The Lutheran World Federation (www.lutheranworld.org/content/ ecumenical-relations) die ondertekening van die dokument as ' $n$ belangrike mylpaal beskryf, moet dié handeling binne 'n bepaalde konteks beoordeel word. Dit vorm deel van ' $n$ voortgaande dialoog tussen die Rooms-Katolieke Kerk en The Lutheran World Federation. In ' $n$ amptelike verklaring (eenstemmig voorberei deur The Congregation for the Doctrine of the Faith en The Pontifical Council for Promoting Christian Unity), wat reeds op 01 November 1999 uitgereik is, stel die Rooms-Katolieke Kerk die volgende: 'The Catholic Church is, however, of the opinion that we cannot yet speak of a consensus such as would eliminate every difference between Catholics and Lutherans in the understanding of justification.

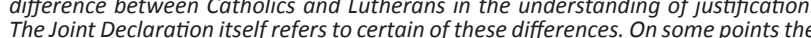
The Joint Declaration itself refers to certain of these differences. On some points the positions are, in fact, still divergent' (The Catholic Church 1999). Aan die Lutherse kant bestaan ook besware en voorbehoude oor The Joint Declaration on the Doctrine of Justification. Van die 124 lidkerke van The Lutheran World Federation het 35 teen die ondertekening van die verklaring gestem. Veral Kerke wat ook lid is van The International Lutheran Council, wat ' $\mathrm{n}$ sterk konfessionele grondslag het, was teen die ondertekening gekant. In Duitsland het 160 professore ook protes aangeteken teen die teologiese inhoud van die verklaring (Jüngel 2011:XI).
}

In die dokument word die volgende ten opsigte van wet en evangelie gestel:

The Reformed agree with the strong conviction expressed that the law is fulfilled in Christ and is not a 'way of salvation' for us. The law discloses our sin to us and leads us to seek God's mercy in Christ. At the same time, we understand that it is the teaching and example of Christ (who fulfilled the law) that remains the norm for life in Christ. For this reason, the Reformed maintain that the commandments of God remain valid for us in our lives as believers. This is the guiding role of the law, sometimes referred to as 'the third use of the law.' This is the primary use in Reformed understanding - even more central than the first two: the 'civil' use (to curb wrongdoing in the public arena) or the 'pedagogical' use in convicting of sin. 'Law and gospel' are not sharply contrasted but viewed as connected by their grounding in God's grace. This sense of connection between law and gospel echoes a Reformed emphasis on the continuity (rather than contrast) between the Old Testament and the New Testament as one covenant of grace. For the Reformed sola scriptura entails tota scriptura. Both law and gospel are God's good gifts to us. The law is God's gracious provision of a guide for living. (World Communion of Reformed Churches 2017:4 [12])

Die standpunt-inname van The World Communion of Reformed Churches is geformuleer in aansluiting by en in reaksie op paragrawe 31-33 van The Joint Declaration on the Doctrine of Justification, wat lui:

\subsection{Law and Gospel}

31. We confess together that persons are justified by faith in the gospel 'apart from works prescribed by the law' (Rom 3:28). Christ has fulfilled the law and by his death and resurrection has overcome it as a way to salvation. We also confess that God's commandments retain their validity for the justified and that Christ has by his teaching and example expressed God's will which is a standard for the conduct of the justified also.

32. Lutherans state that the distinction and right ordering of law and gospel is essential for the understanding of justification. In its theological use, the law is demand and accusation. Throughout their lives, all persons, Christians also, in that they are sinners, stand under this accusation which uncovers their sin so that, in faith in the gospel, they will turn unreservedly to the mercy of God in Christ, which alone justifies them.

33. Because the law as a way to salvation has been fulfilled and overcome through the gospel, Catholics can say that Christ is not a lawgiver in the manner of Moses. When Catholics emphasize that the righteous are bound to observe God's commandments, they do not thereby deny that through Jesus Christ God has mercifully promised to his children the grace of eternal life. (The Lutheran World Federation \& The Catholic Church 1999)

Die Barthiaanse ondertone in die Association of the World Communion of Reformed Churches with the Joint Declaration on the Doctrine of Justification is onmiskenbaar. Die ironie van die World Communion of Reformed Churches se handeling is tweeledig in die sin dat die dokument in 2017 tydens die vyfhonderdjarige viering van die Reformasie aanvaar is en dat dit as 'n gebaar van versoening vir die Lutherse 
kerkgemeenskap aangebied is. Binne 'n konsensus-soekende ekumeniese situasie, kan ons die woorde van Eberhard Jungel (1982b:18) ter harte neem: 'Eine ordentliche Theologie macht keine Kompromisse'. Kompromisloos moet na die waarheid van die evangelie gevra word, om deur teologiese argumentvoering tot ' $n$ gemeenskaplike verstaan van die evangelie te kom (Jüngel 2011:XIX, 42).

Karl Barth het konsekwent weerstand gebied teen elke moontlike vorm van die ideologisering van die evangelie. Sy eie teologie word daarmee egter nie gevrywaar om self as instrument ingespan te word om bepaalde politieke oogmerke te probeer bereik nie (Demut 2016:365). Met 'n behendige (maar deursigtige) kunsgreep, plooi die World Communion of Reformed Churches die verklaring oor die regverdigingsleer om primêr oor sosiale en politieke geregtigheid te handel onder die opskrif The Reformed have particular emphases and additional insights to bring. Die paragraaf oor wet en evangelie (gedeeltelik hierbo aangehaal) dien as votum tot 'n verklaring oor sosiale en politieke geregtigheid. Die oorgang in die argument wat gevoer word, lui soos volg:

The law is God's gracious provision of a guide for living. Reformed sensibilities concerning the law resonate with those expressed in Psalm 19, "The law of the Lord is perfect, reviving the soul; the decrees of the Lord are sure, making wise the simple; the precepts of the Lord are right, rejoicing the heart; the commandment of the Lord is clear enlightening the eyes ...' The renewal of life (sanctification) that accompanies justification strengthens us to live (more fully) in gratitude and joyful obedience to God. (World Communion of Reformed Churches 2017:4 [12])

Toegespits geformuleer, lui die gevolgtrekking:

There is a sense in which justification and sanctification may be thought of as ordered toward justice. In God's saving work things are being 'set right' in lives. We are drawn into right relationship with God and into the true worship of God (soli deo gloria). The true worship of God finds concrete manifestation in striving for justice and righteousness in society. Thus we are drawn into the work of setting things right in the larger social world. (World Communion of Reformed Churches 2017:7 [19])

Die onderliggende verstaan van die verhouding tussen wet en evangelie behels duidelik meer as net 'n blote klemverskuiwing of die aankondiging van addisionele insigte ten opsigte van die klassieke Lutherse posisie. Hoewel die dokument baie na Calvyn verwys, is die gees daarvan Barthiaans. Fundamentele teologiese verskille kom op die tafel en van werklike konsensus met die Lutherse posisie is daar nie sprake nie. In 2007 het die Gemeenskap van Evangeliese Kerke in Europa deur 'n studie bevind dat blywende verskille onder die Europese lidkerke van dié organisasie bestaan betreffende die verstaan van die verhouding tussen wet en evangelie (Bünker \& Friedrich, 2007). Intensiewe studie en openhartige ekumeniese gesprek is nodig om na werklike konsensus te soek ter wille van ' $n$ eenduidige Christelike getuienis in die wêreld (Demut 2016:366).

\section{Erkenning Mededingende belange}

Die outeur verklaar dat hy geen finansiële of persoonlike verbintenis het met enige party wat hom nadelig kon beïnvloed het in die skryf van hierdie artikel nie.

\section{Literatuurverwysings}

Augustine, St., Bishop of Hippo, [412/13] 1914, De spiritu et littera, in W. Bright (ed.) The Clarendon Press, Oxford, viewed 09 January 2018, from https://archive.org/ details/despirituetlitte00augu

Barth, K., 1947, Die Kirchliche Dogmatik, Band I/1: Die Lehre vom Wort Gottes, Evangelischer Verlag, Zollikon-Zürich.

Barth, K., 1948a, Die Kirchliche Dogmatik, Band II/2: Die Lehre von Gott, Evangelischer Verlag, Zollikon-Zürich.

Barth, K., 1948b, Die Kirchliche Dogmatik, Band I/2: Die Lehre vom Wort Gottes, Evangelischer Verlag, Zollikon-Zürich.

Barth, K., 1953, Die Kirchliche Dogmatik, Band IV/1: Die Lehre von der Versöhnung, Evangelischer Verlag, Zollikon-Zürich.

Barth, K., 1955, Die Kirchliche Dogmatik, Band IV/2: Die Lehre von der Versöhnung Evangelischer Verlag, Zollikon-Zürich.

Barth, K., 1959, Die Kirchliche Dogmatik, Band IV/3: Die Lehre von der Versöhnung, Evangelischer Verlag, Zollikon-Zürich.

Barth, K., [1935] 1968, 'Evangelium und Gesetz', in E. Kinder \& K. Haendler (Hrsg.), Gesetz und Evangelium. Beiträge zur gegenwärtigen theologischen Diskussion, pp. 1-29, Wissenschaftliche Buchgesellschaft, Darmstadt.

Bayer, O., 2007, Martin Luthers Theologie, 3. Aufl., J.C.B. Mohr (Paul Siebeck), Tübingen.

Beutel, A., 2010a, 'Theologie als Erfahrungswissenschaft', in A. Beutel (Hrsg.), Luther Handbuch, 2. Aufl., S. pp. 454-459, J.C.B. Mohr (Paul Siebeck), Tübingen.

Beutel, A., 2010b, 'Theologie als Schriftauslegung', in A. Beutel (Hrsg.), Luther Handbuch, 2. Aufl., S. pp. 444-449, J.C.B. Mohr (Paul Siebeck), Tübingen.

Beutel, A., 2010c, 'Theologie als Unterscheidungslehre', in A. Beutel (Hrsg.), Luther Handbuch, 2. Aufl., S. 450-454, J.C.B. Mohr (Paul Siebeck), Tübingen.

Bultmann, R., 1976, Der zweite Brief an die Korinther, Vandenhoeck \& Ruprecht, Göttingen.

The Catholic Church, 1999, Response of the Catholic Church to the Joint Declaration of the Catholic Church and the Lutheran World Federation on the Doctrine of Justification, viewed 01 March 2018, from http://www.vatican.va/roman curia/ pontifical councils/chrstuni/documents/rc_pc_chrstuni_doc_01081998_offanswer-catholic en.htm

Calvino, J., 1559, Institutio christianae religionis, Oliua Roberti Stephani, Genèvae, viewed 07 February 2018, from https://archive.org/details/institutiochrist1559calv

Danz, C., 2013, Einführung in die Theologie Martin Luthers, Wissenschaftliche Buchgesellschaft, Darmstadt.

Demut, A., 2016, 'Evangelium und Gesetz', in M. Beintker (Hrsg.), Barth Handbuch, pp. 361-367, J.C.B. Mohr (Paul Siebeck), Tübingen.

Dingel, I. (Bearbeiter), [1577] 2014, 'Die Konkordienformel' in I. Dingel (Hrsg.), Die Bekenntnisschriften der evangelisch-lutherischen Kirche, Vollständige Neuedition, pp. 1184-1610, Vandenhoeck \& Ruprecht, Göttingen.

Ebeling, G., 1967a, 'Erwägungen zur Lehre vom Gesetz', in G. Ebeling (Hrsg.), Wort und Glaube, 1. Bd., 3. Aufl., S. pp. 255-293, J.C.B. Mohr (Paul Siebeck), Tübingen.

Ebeling, G., 1967b, 'Zur Lehre vom triplex usus legis in der reformatorischen Theologie', in G. Ebeling (Hrsg.), Wort und Glaube, 1. Bd., 3. Aufl., S. pp. 50-68, J.C.B. Mohr (Paul Siebeck), Tübingen.

Ebeling, G., 1985, 'Karl Barths Ringen mit Luther', in G. Ebeling (Hrsg.), Lutherstudien, 3. Bd., Begriffsuntersuchungen - Textinterpretationen - Wirkungsgeschichtlichen, S. pp. 428-573, J.C.B. Mohr (Paul Siebeck), Tübingen.

Ebeling, G., 2006, Luther: Einführung in sein Denken. Mit einem Nachwort von Albrecht Beutel, 5. Aufl., J.C.B. Mohr (Paul Siebeck), Tübingen.

Elert, W., 1948, Zwischen Gnade und Ungnade, Abwandlungen des Themas Gesetz und Evangelium, Evangelischer Presseverband für Bayern, München.

Greschat, M., 2016, 'Barth und die Politik', in M. Beintker (Hrsg.), Barth Handbuch, S. pp. 153-158, J.C.B. Mohr (Paul Siebeck), Tübingen.

Hegel, G.W.F., 1978, 'Vorlesungen über die Philosophie der Religion II', in E. Moldenhauer \& M. Michel (Hrsg.), G.W.F. Hegel, Werke in zwanzig Bände, Bd. 17, Suhrkamp Verlag, Frankfurt am Main.

Honecker, M., 1990, Einführung in die Theologische Ethik. Grundlagen und Grundbegriffe, Walter de Gruyter \& Co., Berlin.

Ioannis Pauli PP. II, 1993, Summi Pontificis, Veritatis Splendor, Litterae Encyclicae, Cunctis catholicae ecclesiae episcopis de quibusdam quaestionibus fundamentalibus doctrinae moralis ecclesiae, Libreria Editrice Vaticana, Vatican viewed 09 January 2018, from http://w2.vatican.va/content/john-paul-ii/la/ encyclicals/documents/hf_jp-ii_enc_06081993_veritatis-splendor.html

Jüngel, E., 1982a, 'Evangelium und Gesetz. Zugleich zum Verhältnis von Dogmatil und Ethik', in E. Jüngel (Hrsg.), Barth-Studien, S. pp. 180-209, Benziger Verlag, Zürich-Köln. 
Jüngel, E., 1982b, 'Karl Barth', in E. Jüngel (Hrsg.), Barth-Studien, S. pp. 15-21, Benziger Verlag, Zürich-Köln.

Jüngel, E., 2011, Das Evangelium von der Rechtfertigung des Gottlosen als Zentrum des christlichen Glaubens, vol. 6, Aufl., J.C.B. Mohr (Paul Siebeck), Tübingen.

Luther, M., [1520/1521] 1897, 'Schriften, Predigten, Disputationen 1520/21', in P. Pietsch (Hrsg.), D. Martin Luthers Werke, Kritische Gesamtausgabe, 7. Bd., Hermann Böhlaus Nachfolger, Weimar, [WA 7], viewed 14 February 2018, from https://archive.org/details/werkekritischege07luthuoft

Luther, M., [1525] 1908, 'Schriften 1525', in K. Dreicher (Hrsg.), D. Martin Luther Werke, Kritische Gesamtausgabe, 18. Bd., Hermann Böhlaus Nachfolger, Weimar, [WA 18], viewed 14 February 2018, from https://archive.org/details/ werkekritischege18luthuoft

Luther, M., [1532] 1909, 'Predigten 1532', in K. Dreicher (Hrsg.), D. Martin Luthers Werke, Kritische Gesamtausgabe, 36. Bd., Hermann Böhlaus Nachfolger, Weimar, [WA 36], viewed 14 February 2018, from https://archive.org/details/ werkekritischege36luthuoft

Luther, M., [1522] 1910c, 'Weihnachtspostille 1522', in K. Dreicher (Hrsg.), D. Martin Luthers Werke, Kritische Gesamtausgabe, 10. Bd., Erster Abteilung, 1. Hälfte, Hermann Böhlaus Nachfolger, Weimar, [WA 10, I, 1], viewed 14 February 2018 from https://archive.org/details/werkekritischege10luthuoft

Luther, M., [1531/1535] 1911, 'In epistolam S. Pauli ad Galatas Commentarius ex praelectione', in K. Dreicher (Hrsg.), D. Martin Luthers Werke, Kritische Gesamtausgabe, 40. Bd., Erster Abteilung, Hermann Böhlaus Nachfolger, Weimar, [WA 40, I], viewed 14 February 2018, from https://archive.org/details/ werkekritischege40luthuoft

Luther, M., [1530-1535] 1912, 'Tischreden aus der ersten Hälfte der dreißiger Jahre', in K. Dreicher (Hrsg.), D. Martin Luthers Werke, Kritische Gesamtausgabe, Tischreden 1531-1546, 5. Bd., Hermann Böhlaus Nachfolger, Weimar, [WA TR 1], viewed 14 February 2018, from https://archive.org/details/werketischreden10201luthuoft

Luther, M., [1540-1544] 1919, 'Tischreden aus den Jahren 1540-1544', in K. Dreicher (Hrsg.), D. Martin Luthers Werke, Kritische Gesamtausgabe, Tischreden 15311546, 5. Bd., Hermann Böhlaus Nachfolger, Weimar, [WA TR 5], viewed 14 February 2018, from https://archive.org/details/werketischreden10205luthuoft
Luther, M., [1533/1538] 1926, 'Disputationen 1533/1538', in K. Dreicher (Hrsg.), D. Martin Luthers Werke, Kritische Gesamtausgabe, 39. Bd., Erster Abteilung, Hermann Böhlaus Nachfolger, Weimar, [WA 39, I], viewed 14 February 2018, from https://archive.org/details/werkekritischeg3901luthuoft

The Lutheran World Federation \& The Catholic Church, 1999, Joint Declaration on the Doctrine of Justification, viewed 01 March 2018, from http://www.vatican.va/ roman curia/pontifical councils/chrstuni/documents/rc pc chrstuni doc 31101999_cath-luth-joint-declaration_en.html

The Lutheran World Federation, 2018, The Lutheran World Federation Official Site, viewed 01 March 2018, from www.lutheranworld.org

Maurer, E., 2016, 'Barth und das Luthertum', in M. Beintker (Hrsg.), Barth Handbuch, S pp. 127-131, J.C.B. Mohr (Paul Siebeck), Tübingen.

Melanchthon, P., [1521] 1997, Loci Communes, Lateinisch - Deutsch, Übersetzt und mit kommentierenden Anmerkungen versehen von Horst Georg Pöhlmann, Herausgegeben vom Lutherischen Kirchenamt der Verenigten EvangelischLutherischen Kirche Deutschlands, Gütersloher Verlagshaus, Gütersloh.

Melanchthon, P., [1553] 2010, Heubartikel Christlicher Lere, Melanchthons deutsche Fassung seiner Loci theologici, nach dem Autograph und dem Originaldruk von 1553 herausgegeben von Ralf Jenett und Johannes Schilling, Evangelische Verlagsanstalt, Leipzig.

Plasger, G., 2016, 'Luther und Calvin', in M. Beintker (Hrsg.), Barth Handbuch, S. pp. 37-42, J.C.B. Mohr (Paul Siebeck), Tübingen.

Schlink, E., 1956, 'Gesetz und Paraklese', in E. Wolf, C. von Kirschbaum \& R. Frey (Hrsg.), Antwort: FS Karl Barth, pp. 323-335, Evangelischer Verlag, Zollikon.

Schlink, E., 1983, Ökumenische Dogmatik, Grundzüge, Vandenhoeck \& Ruprecht, Göttingen.

Van Wyk, G., 2017, Die waarheid van die evangelie: Nadenke oor die Brief aan die Galasiërs, in N. Van Wyk (Red.), Tydskrif vir Hervormde Teologie 5(2), viewed 18 April 2017, from http://www.nhka.org/publikasies/THT

World Communion of Reformed Churches, 2017, Association of the World Communion of Reformed Churches with the Joint Declaration on the Doctrine of Justification, World Communion of Reformed Churches, Hannover. 